\title{
Urgently needed: Climate lawyers
}

Citation for published version (APA):

Faure, M., \& Liu, J. (2018). Urgently needed: Climate lawyers. Climate Law, 8(3), 161-171.

https://doi.org/10.1163/18786561-00803003

Document status and date:

Published: 01/01/2018

DOI:

10.1163/18786561-00803003

Document Version:

Publisher's PDF, also known as Version of record

Document license:

Taverne

\section{Please check the document version of this publication:}

- A submitted manuscript is the version of the article upon submission and before peer-review. There can be important differences between the submitted version and the official published version of record.

People interested in the research are advised to contact the author for the final version of the publication, or visit the DOI to the publisher's website.

- The final author version and the galley proof are versions of the publication after peer review.

- The final published version features the final layout of the paper including the volume, issue and page numbers.

Link to publication

\footnotetext{
General rights rights.

- You may freely distribute the URL identifying the publication in the public portal. please follow below link for the End User Agreement:

www.umlib.nl/taverne-license

Take down policy

If you believe that this document breaches copyright please contact us at:

repository@maastrichtuniversity.nl

providing details and we will investigate your claim.
}

Copyright and moral rights for the publications made accessible in the public portal are retained by the authors and/or other copyright owners and it is a condition of accessing publications that users recognise and abide by the legal requirements associated with these

- Users may download and print one copy of any publication from the public portal for the purpose of private study or research.

- You may not further distribute the material or use it for any profit-making activity or commercial gain

If the publication is distributed under the terms of Article $25 \mathrm{fa}$ of the Dutch Copyright Act, indicated by the "Taverne" license above, 


\title{
Urgently Needed: Climate Lawyers
}

\author{
Michael Faure \\ Maastricht European Institute for Transnational Legal Research (METRO), \\ Maastricht University \\ michael.faure@maastrichtuniversity.nl \\ Jing Liu \\ Research Institute of Environmental Law, Wuhan University \\ liujoyjing@163.com
}

\begin{abstract}
We argue that climate law has specific features-including scientific complexity, a strongly transboundary nature, and long-term effects - that make it more challenging to study than other more traditional domains of environmental law. As a consequence, an interdisciplinary perspective may be needed even more for climate law than for the traditional study of environmental law. Climate law is to some extent underestimated by scientists, who should realize that for effective mitigation of greenhouse gases and adaptation to climate change, an optimal design and enforcement through climate law is necessary. Climate law can be expected to become more important with the implementation of the Paris Agreement, and for that reason climate lawyers should receive a more prominent position in the international policy arena of climate change.
\end{abstract}

\section{Keywords}

environmental principles - interdisciplinarity - enforcement - smart instrument mixes - emission-trading scheme - climate lawyers

1 We are very grateful to Marjan Peeters (Maastricht University) for providing us with useful comments on an earlier version of this article. 
The question whether climate law is a new sub-discipline/domain is probably not the most challenging or interesting one. It seems a bit like the quest of a particular interest group (in casu, the climate lawyers) to seek recognition. We have seen similar tendencies in the past when sub-disciplines such as construction law, consumer law, or computer law emerged, and the same is true of the emergence of environmental law. ${ }^{2}$ To some extent one can understand a lobby for the recognition of new sub-disciplines in law as autonomous, as they need to find their place among the well-established, traditional fields of constitutional, administrative, tort, contract, and criminal law. Obviously this struggle for recognition of a particular sub-discipline could have practical consequences. It could lead to recognition among funding organizations (and thus to research grants); and, when determining the teaching curriculum at law schools, the recognition of a field of law as an autonomous discipline may have advantages, if only that it may lead to the creation of a chair, or an institute, and thus to jobs in the subject area.

A similar struggle for recognition has been undertaken by the adjacent domain of environmental law. ${ }^{3}$ Compared to the more traditional branches of law, a feature common to environmental and climate law is that they both have a strongly intradisciplinary character, meaning that the study of environmental and climate law cannot be limited to one particular legal sub-discipline. Even though environmental law may in most countries (and in scholarship)

2 On the emergence of global climate law, see Daniel A. Farber and Marjan Peeters, 'The Emergence of Global Climate Law', in Climate Change Law, edited by Daniel A. Farber and Marjan Peeters (Cheltenham: Edward Elgar, 2016), at 687-702.

3 In spite of the different definitions of "discipline", it is a complex concept touching on different issues such as the goals, objects of study, terminology, research methods, and academic communities. See Douglas W. Vick, 'Interdisciplinarity and the Discipline of Law', 31(2) Journal of Law and Society 163 (2004). This paper will not delve into the bitter dispute on what constitutes a discipline but treat law itself as one discipline. Traditional branches of law, such as civil law, administrative law, and criminal law rely on different tools for solving social problems (such as recognizing the equal status of private parties and using top-down administrative orders or penalties). A few newly emerged social problems, such as the insufficient protection of the interests of consumers and environmental deterioration, also need legal intervention. To solve such problems, a combination of different legal tools (private, administrative, or criminal law tools) is necessary. For the convenience of discussion, different terms are used to denote to the branches of law in this article. The traditional branches are referred as sub-disciplines, and newly emerged branches with an intradisciplinary approach are referred to as domains (with the focus on the object of study rather than the methods/ tools used). 
have emerged as a sub-branch of administrative law, it now includes aspects of almost all legal sub-disciplines, such as (in addition to international law) human rights law and constitutional law, but certainly also private law (e.g. contract and tort). Environmental law moreover needs the input of criminal law on the topic of enforcement, and of tax law on the topic of environmental charges.

It could be argued that similar challenges of combining different legal subdisciplines also arise in the domain of climate law. ${ }^{4}$ All of the above features that necessitate a combination of different legal sub-disciplines in environmental law are true of climate law as well. ${ }^{5}$ This creates specific challenges for scholars examining climate law. Even though most scholars and practitioners will have a legal sub-discipline from which they approach climate law (e.g. international law or administrative law), it is equally clear that it is a domain in which one cannot afford to limit oneself. A good knowledge of how different legal instruments work in fighting climate change is of crucial importance.

The intradisciplinary character of climate law is a challenge as well as a luxury. The luxury aspect is related to the fact that the climate lawyer does not, and cannot, limit himself or herself to merely studying climate change from one particular perspective. Climate law therefore necessarily invites study from the perspective of different legal sub-disciplines. But that luxury (of being able to address the problem from different perspectives) also creates challenges, as not all climate lawyers may have sufficient knowledge of all the various legal sub-disciplines which are implied in a thorough study of the climate change problem.

\section{Specific Features of Climate Law}

Climate law has rapidly developed in recent decades, with the accumulation of international regulation, legislative efforts, and cases. ${ }^{6}$ Its relationship with environmental law has attracted academic attention. On the one hand, climate

4 See Farber and Peeters, supra note 2, at 688, who argue that climate lawyers are posed "with the difficult task of mastering different disciplines of law, including inter alia, international public law, administrative law, tort law, insurance law and land-use law".

5 Meanwhile, in addition to climate change law there are other subfields of environmental law that have been developed. One may point to nature-conservation law and access to justice in environmental matters.

6 Jacqueline Peel, 'Climate Change Law: The Emergence of a New Legal Discipline', 32 Melbourne University Law Review 922 (2008). 
law and environmental law share many similarities. Climate change is often regarded as a type of environmental problem. ${ }^{7}$ Similar instruments and governance strategies are used in both climate law and environmental law. ${ }^{8}$ It is common to find environmental law issues framed in climate law terms and vice versa. ${ }^{9}$ However, the differences between the two branches are increasingly noted as well. For example, Zahar pointed out that environmental law and climate law address different types of environmental damage (with the latter limited to cumulative damage). Given this difference, some principles of environmental law may not apply in climate law. ${ }^{10}$ The difference in liability rules of environmental law and climate law has also been noted. ${ }^{11} \mathrm{~A}$ comprehensive overview of the differences between environmental law and climate law is out of scope here. We focus instead on two features of climate change: the high extent of uncertainty and the interdisciplinary approach.

One feature of climate law that makes the study of the applicable legal instruments even more challenging is the much larger degree of scientific complexity compared to more traditional domains of environmental law. ${ }^{12}$ Exaggerating only slightly, within traditional environmental law it may still be possible to have some idea about the causes of environmental problems, about the remedies that could be employed to solve an environmental problem, and therefore about the legal and policy instruments best used to address a particular environmental problem. ${ }^{13}$ Even though in environmental law there may also

Jekwu Ikeme, 'Climate Change Adaptational Deficiencies in Developing Countries: The Case of Sub-Saharan Africa', 8(1) Mitigation and Adaptation Strategies for Global Change 29 (2003).

8 Chris Hilson, 'It's All About Climate Change, Stupid! Exploring the Relationship Between Environmental Law and Climate Law', 25(3) Journal of Environmental Law 359 (2013).

9 Ibid., at 362; Chidi Odozor and Kola O. Odeku, 'Explaining the Similarities and Differences between Climate Law and Environmental Law', 45(2)Journal of Human Ecology 127 (2014), at 132 .

10 Alexander Zahar, 'Mediated versus Cumulative Environmental Damage and the International Law Association's Legal Principles on Climate Change', 4(3) Climate Law 217 (2014); Alexander Zahar, 'Methodological Issues in Climate Law', 5(1) Climate Law 25 (2015). Different ideas exist in whether the prevention principle is applicable in the climate context: see, for example, Benoit Mayer, 'The Applicability of the Principle of Prevention to Climate Change: A Response to Zahar', 5(1) Climate Law 1 (2015). Richard Lord, et al. (eds.), Climate Change Liability: Transnational Law and Practice (New York: Cambridge University Press, 2012).

On the importance of uncertainty in the relation to climate change risks, see Nicolas de Sadeleer, 'The Precautionary Principle and Climate Change', in Climate Change Law, edited by Daniel A. Farber and Marjan Peeters (Cheltenham: Edward Elgar, 2016), at 21-22.

13 Generally on the question of instrument choice in environmental law, see Richard B. Stewart, 'Instrument Choice', in The Oxford Handbook of International Environmental Law, 
exist uncertainty (this being one of the reasons why the precautionary principle has been widely advocated in the domain of environmental law), ${ }_{1}^{14}$ for most of the point-source-pollution problems with which environmental law has been preoccupied, there exists a reasonable amount of scientific information about cause-effect relationships. But the uncertainty that exists concerning the impacts of climate change, ${ }^{15}$ the fact that we are dealing not only with pointsource pollution (including from largely known industrial emitters) but also with positive feedback mechanisms (e.g. a melting permafrost with resulting methane emissions), ${ }^{16}$ makes regulating the sources of climate change much more complicated. Greenhouse gas emissions have effects of a strongly transboundary nature and operate over a long time-period. This creates additional scientific complexity and more challenges for the regulator than those found in traditional problems of environmental law. ${ }^{17}$ Complexity is one of the greatest challenges for the domain of climate law. It also makes clear that, while traditional environmental law needs to cross boundaries and work with adjacent disciplines, this becomes even more necessary in climate law. Indeed, traditional environmental lawyers could use insights from different legal fields to search for the optimal legal instrument to deal with a specific environmental issue. They could thus remain within the legal discipline. Given the enormously complex scientific dimensions concerning the climate change problem, it is virtually impossible for a climate lawyer to function simply by remaining within the legal field and not looking around for insights from other domains.

As a starting point, a climate lawyer will need to have at least some understanding of the scientific dimensions of the climate change issue, and be able to read and apprehend, for example, some of the reports of the IPCC, ${ }^{18}$ which

edited by Daniel Bodansky, Jutta Brunnée, and Ellen Hey (Oxford University Press, 2007), at $147-181$.

14 Nicolas De Sadeleer, Environmental Principles: From Political Slogans to Legal Rules (Oxford: Oxford University Press, 2002), at 91-226.

15 Although there is a wide consensus within the IPCC that human influence on the climate system is clear, it remains difficult to indicate or predict where particular effects will emerge.

16 Further on regulating methane hydrates, see Roy A. Partain, Mechanism Design for the Fiery Ice: Civil Liability and Regulations for the Efficient Governance of the Environmental Hazards from Offshore Methane Hydrate Operations (2014) (unpublished PhD dissertation, Erasmus University Rotterdam).

17 See Richard B. Stewart and Jonathan B. Wiener, Reconstructing Climate Policy. Beyond Kyoto (Washington: AEI Press, 2003), at 2-3.

18 The IPCC published its 5 th assessment report in 2014; <www.ipcc.ch>. See IPCC, Climate Change, 2014: Synthesis report: Contribution of Working Groups I, II and III to the 5th Assessment Report of the IPCC (Cambridge: Cambridge University Press, 2014). 
often constitute the basis for further agreements taken by the cops in furtherance of the UNFCCC. But especially in a domain like climate change, where there is so much scientific complexity, where the potential damage is enormous, and where adequate remedies may cause fundamental lifestyle changes, it requires much more effort to create consensus on action among international actors. Climate lawyers therefore need to have a good insight into international relations and international politics as well as a good understanding of what may motivate states (and specific stakeholders within states) to agree to take action. Such insights into the specific drivers, motivations, and incentives of the stakeholders are crucial for a better understanding of the adequacy and appropriateness of the instruments to be employed. Similar arguments could be made about the necessity of including insights from political science, economics, and sociology, among other disciplines. What makes climate law probably different, and therefore not just a subfield of traditional environmental law, is the need for a truly interdisciplinary approach. Multidisciplinarity can help the understanding of environmental law as well, for example when considering measures to protect tropical forests and whales or to regulate chemicals. However, it is still a kind of luxury in traditional environmental law. It is common for traditional environmental lawyers to use insights from different legal fields to search for the optimal legal instrument to deal with the specific environmental issue, thus remaining within the legal discipline. However, as discussed, a multidisciplinary approach is a necessity in climate law. Moreover, the development of climate law needs not only to borrow insights from science, political science, economics, and other disciplines, but also to meld together knowledge from different disciplines to search for solutions. Hence, an interdisciplinary approach is necessary.

Having formulated these thoughts on what makes climate law a special field of interest, we can now turn to the more difficult question (than whether it is a separate, legal discipline) of what are the future challenges for climate lawyers. ${ }^{19}$ One of the most important issues for climate lawyers is to make themselves felt even more strongly than they have done so far in academia and on the international stage. The plea that we have just made for climate lawyers to keep an open mind and not just to focus on their own legal discipline but also

19 For an elaboration of an equally interesting set of challenges in the field of climate law, see Farber and Peeters, supra note 2, at 699 . 
to incorporate insights from other disciplines into their work, may strike some climate lawyers as pushing on an open door-for it is something that they do on a daily basis. Unfortunately, one must observe, especially in academic circles, but sometimes also at the policy level, that the opposite is not always true. In some cases, ambitious and technically complicated research projects are set up related to climate change, where only scientists cooperate and lawyers are largely absent. There are, for example, projects that explore alternatives to mitigation of greenhouse gases, such as geoengineering or carbon capture and storage, without any involvement of lawyers, although many legal questions arise. An important task of lawyers is to work themselves into that research agenda, not so much so as to obtain research funding (which obviously is a nice secondary benefit), but for the simple reason that climate change scientists should realize that, for the implementation of their ideas, it is absolutely necessary to have some involvement of climate lawyers.

For example, in the domain of adaptation, a lot of research is undertaken indicating which areas will suffer from drought and which will be flooded. Often this leads to the realization that measures should be taken to protect potential victims of flooding with adequate compensation. But the implementation of those ideas may need climate lawyers to explain how a system of comprehensive insurance or another sound solution could be designed and implemented. Climate lawyers are specialized in examining the pros and cons of various legal and policy instruments (including command-and-control, financial, and market-based instruments) to translate scientific evidence to the policy level (in collaboration with other disciplines), with respect to both mitigation (e.g. providing incentives for mitigation ${ }^{20}$ and adaptation. ${ }^{21}$ Climate lawyers have gained valuable insights into "what works", for example by incorporating insights from theories of so-called smart instrument mix, ${ }^{22}$ but also from theories concerning responsive regulation. ${ }^{23}$ The latter can explain under which conditions (including different variables such as country-specific characteristics, the

20 Further on the instrument choice for climate change policy, see David Benson and Andrew Jordan, 'Climate Policy Instrument Choices', in Climate Change Law, edited by Daniel A. Farber and Marjan Peeters (Cheltenham: Edward Elgar, 2016), at 57-67.

21 See Michael B. Gerrard and Katrina Fisher-Kuh (eds.), The Law of Adaptation to Climate Change: $U$ s and International Aspects (Chicago: American Bar Association, 2012).

22 See in that respect, among others, Neil Gunningham, 'Environmental Law, Regulation and Governance: Shifting Architectures', 21(2) Journal of Environmental Law 179 (2009), and Neil Gunningham, Peter Grabosky, and Darren Sinclair, Smart Regulation:Designing Environmental Policy (New York: Oxford University Press, 1998).

23 See Ian Ayres and John Braithwaite, Responsive Regulation: Transcending the Deregulation Debate (Oxford: Oxford University Press, 1992). 
nature of the industry in question, and the properties of the emissions) particular (combinations of) instruments may be more likely to be accepted at the policy level and better able to accomplish specific policy goals.

The message is therefore clear: climate law is a discipline that has been around for two decades or more, and climate lawyers, as specialists in this domain should not be overly modest, but instead should be more ambitious: they should go out and persuade the community of climate change scientists that it needs to closely collaborate with climate lawyers if it wants the results of its work to be taken into account at the policy level. This is the domain in which climate lawyers have acquired a great deal of expertise over the past decades.

The need to borrow insights from other disciplines and to work together with the community of climate change scientists does not undermine the importance of doctrinal analysis. A truly interdisciplinary approach is, after all, not about putting old wine in new bottles, but about taking full advantage of the core field of expertise in each discipline and accumulating new knowledge based on cross-fertilization.

A Research Agenda: Examples

Four examples illustrate the important contribution of climate lawyers to the field of climate change studies. First, we have already mentioned that both greenhouse gas mitigation and adaptation to climate change are domains which are so complex that there is not one traditional legal instrument that is able to reach the goals set by the policymaker. It is for this reason that policymakers often combine particular policy instruments. Yet, it is quite important to verify how different instruments (e.g. a financial levy or emission trading) can positively reinforce each other in given circumstances. If such a mutual reinforcement would take place, there could be a smart instrument mix, increasing the effectiveness of the regulatory regime. If, to the contrary, instruments are designed separately without taking into account their interdependencies, there is a danger of an "instrument mess", ${ }^{24}$ which could have adverse effects as far as reaching the policy goals is concerned. Climate lawyers, but also other social scientists (such as political scientists), are specialists in designing

24 Marjan Peeters, 'Instrument Mix or Instrument Mess? The Administrative Complexity of the EU Legislative Package for Climate Change', in EU Environmental Legislation: Legal Perspectives on Regulatory Strategies, edited by Marjan Peeters and Rosa Uylenburg (Cheltenham: Edward Elgar, 2014), at 173-192. 
smart instrument mixes, and further research in this domain still needs to be carried out.

Another fascinating example of the importance of the contribution of lawyers is the work done by various groups developing legal principles of climate law. One example is the legal principles relating to climate change developed by the International Law Association during its 76 th conference in April $2014 ;{ }^{25}$ another is the work by Jaap Spier and his team on principles on global climate obligations ${ }^{26}$ and the obligations of enterprises. ${ }^{27}$ This type of exercise is crucial, as it is undertaken by top lawyers (including members of the highest courts and accomplished academics). Although there is an activist nature to such principles, their main goal is to show what are the specific implications of legal rules, for example for the obligations of emitters of greenhouse gases but also of financial institutions investing in enterprises that emit greenhouse gases. The fact that those groups have used legal analysis to clarify the scope of legal obligations will be of crucial importance, including at the policy level. The relevance of this type of work cannot be overemphasized and more debate should take place on how the law can be interpreted in view of potential climate liabilities.

A third crucially important aspect of climate change legal research is that it has become-due in part to collaboration with economists and other social scientists-increasingly empirical. Climate lawyers have examined the effectiveness of legal and policy instruments with respect to many different questions. Take the EU ETS. Numerous studies have examined to what extent, prior to the implementation of the EU ETS, large emitters reduced greenhouse gas emissions. ${ }^{28}$ Such studies are clearly not undertaken by climate lawyers alone. Lawyers draw on the results of such studies for their instrument design.

25 Further on the work of the ILA and an interesting comparison with the principles developed by Spier and his group, see Marjan Peeters, 'Environmental principles in international climate change law', in Principles of Environmental Law, edited by Ludwig Krämer and E. Orlando (Cheltenham: Edward Elgar, 2018), forthcoming.

26 Expert Group on Global Climate Obligations, Oslo Principles on Global Climate Obligations (The Hague: Eleven, 2015).

27 Jaap Spier and Expert group on Global Climate Change, Principles on Climate Obligations of Enterprises (The Hague: Eleven, 2017).

28 See Onno Kuik and Frans Oosterhuis, 'Economic Impacts of the EU ETs: Preliminary Evidence', in Climate Change and European Emissions Trading: Lessons for Theory and Practice, edited by Michael Faure and Marjan Peeters (Cheltenham: Edward Elgar, 2008), at 208-225; and see Denny Ellerman and Barbara Buchner, Over-allocation or Abatement? A Preliminary Analysis of the EU ETS Based on the 2005 Emissions Data (FEEM Working Paper, 2006), at 139. 
These studies focusing on the effectiveness of the instruments used are of crucial importance, as their results can be implemented at the policy level and therefore lead to a dynamic policy process whereby instruments can be adapted and refined, taking into account the insights from those empirical studies. ${ }^{29}$

An important aspect of the effectiveness of the regulation of climate change relates to issues of compliance and enforcement. ${ }^{30}$ All too often one has the impression that policymakers or economists think that there is less need for regulation where a market-based instrument, such as emission trading, is to be introduced. Several scholars have rightly pointed out that market-based instruments in fact only work where there is an adequate regulatory framework and where sufficient attention is paid to the regulation of compliance and enforcement. This has been shown to be of crucial importance in the implementation of the EU ETS, ${ }^{31}$ but questions concerning enforcement and compliance will also be crucial in the implementation of the Paris Agreement. ${ }^{32}$ This is an example of a fourth area where climate lawyers can make an important contribution. Lawyers have traditionally paid much attention to the effectiveness of different enforcement mechanisms and have also shown how the design of a compliance and enforcement mechanism is crucial for the overall effectiveness of a regulatory regime, including in the domain of climate law.

\section{Increasing Importance of Climate Law(yers)}

Finally, it should be stressed that one can expect the importance of climate law (and therefore lawyers) only to increase. Take the implementation of the Paris Agreement. This raises many questions, for example, on how the Nationally Determined Contributions will be determined; ${ }^{33}$ how it will be assessed

29 See Michael Faure, 'Effectiveness of Environmental Law: What Does the Evidence Tell Us?', 36(2) William and Mary Environmental Law and Policy Review 293 (2012), at 315-319.

30 See, in that respect, Sebastian Oberthür and Eliza Northrop, 'Towards an Effective Mechanism to Facilitate Implementation and Promote Compliance under the Paris Agreement', 8(1) Climate Law, 39 (2018), at 39-69.

31 See Marjan Peeters, 'Enforcement of the Eu Greenhouse Gas Emissions Trading Scheme', in Kurt Deketelaere and Marjan Peeters, EU Climate Change Policy: The Challenge of New Regulatory Initiatives (Cheltenham: Edward Elgar, 2006), at 169-187.

32 See, in that respect, Benoit Mayer, 'Construing International Climate Change Law as a Compliance Regime', 7(1) Transnational Environmental Law 115 (2018), at 115-137; and Oberthür and Northrop, supra note 30.

33 See Guri Bang, Jon Hovi, and Tora Skodvin, 'The Paris Agreement: Short-Term and LongTerm Effectiveness', 4(3) Politics and Governance 209 (2016); and Lavanya Rajamani, 
whether the NDCs will actually contribute to the goals of the Paris Agreement; and how compliance with the NDCs will be verified. ${ }^{34}$ Many questions also remain in relation to the North-South relationship. The common notion that mitigation gains can be more plentifully obtained in developing countries raises important questions about the North-South relationship when one considers that an important way of reducing emissions from greenhouse gases is to better protect rainforests in the Amazon, Indonesia, and elsewhere. This raises many legal issues concerning the possibility of taking measures in the North (e.g. at the Eu level) that have extraterritorial effect in the South, while ensuring compatibility with obligations under international law. Questions also arise as to how donors from the North can subsidize climate-changerelated activities in the South by adequately monitoring the investments of all stakeholders involved (for example in a forestry project) to invest in longterm sustainability while abstaining from neo-colonialism disrespectful of the sovereignty of Southern states. Much research has already been done on these questions, ${ }^{35}$ but much more remains to be explored.

Similar questions also arise with respect to, for example, emissions from shipping and aviation and related so-called offsetting mechanisms. ${ }^{36}$ Again, we need the expertise of climate lawyers on what may be the most appropriate instruments to provide incentives to reduce those emissions: how can particular instruments be designed in a smart manner and how can commitments be verified? - and all of this in compliance with existing legal principles.

Many more examples of pressing questions could be provided. The general point is that it probably does not matter whether climate law is or should be a separate legal discipline. The most important point to stress is that it is unthinkable that we could adequately deal with the climate change problem without input from lawyers having an expertise in the many legal aspects that touch upon the climate change problem. The lesson therefore is clear: more than ever, the world needs climate lawyers!

'Ambition and Differentiation in the 2015 Paris Agreement: Interpretative Possibilities and Underlying Politics', 65(2) International Commercial Law Quarterly 493 (2016).

34 See Mayer, supra note 32.

35 See, inter alia, Joanne Scott, 'Extraterritoriality and Territorial Extension in EU Law', 62(1) American Journal of Comparative Law 87 (2014); Sebastien Jodoin, Forest Preservation in a Changing Climate REDD+ and Indigenous and Community Rights in Indonesia and Tanzania (Cambridge: Cambridge University Press, 2017).

36 On those issues see, inter alia, Kati Kulovesi and Joanna Dafoe, 'Існо and гмо: International Sectoral Approaches to Greenhouse Gas Reductions in Transport', in Climate Change Law, edited by Daniel A. Farber and Marjan Peeters (Cheltenham: Edward Elgar, 2016), at $274-285$. 